\title{
Editorial independence for CMAJ: signposts along the road
}

\author{
Published at www.cmaj.ca on Aug. 3, 2006.
}

$\mathrm{T}$ he CMAJ Governance Review Panel, formed in March 2006 to "review the $C M A$ 's governance structure and to provide objective recommendations to further the $C M A F$ 's continued commitment to editorial independence and maintaining excellence in reporting on the science and the art of medicine," released its final report on July I4, 2006. ${ }^{1}$ Many of its recommendations are in keeping with our submission to the panel. ${ }^{2}$ The CMA's rapid acceptance of all 25 recommendations $^{3}$ and initiation of steps to implement them is a strong and welcome signal that the CMA is committed to upholding the editorial independence of CMAJ.

The principles of editorial independence are enshrined in the new governance structure, along with clear lines of communication, authority and accountability, thus ensuring that the Editor-in-Chief will have full control over editorial content, irrespective of the topic. To make clear to readers that editorial content does not necessarily reflect CMA policy, the disclaimer that currently appears on the editorial page and in the table of contents will be more prominent, and all editorials will be signed. As a matter of courtesy, the journal will continue to give the CMA the same advance notice as it gives the media concerning editorial content, but the CMA will have no right or ability to influence the publication of that content. Instead, CMA, like any one else, may submit its opinion as a commentary or other article, which will undergo the usual review process before its merit for publication is weighed. The significance and value of a formal $C M A J$ mission statement (Box I) is highlighted in the report, including its importance in hiring the Editor-in-Chief, evaluating the performance of $C M A J$ and the Editor-in-Chief, and resolving conflicts. The ownership of CMAJ has been transferred from CMA Holdings, a subsidiary that manages many CMA businesses, back to CMA in proper (as the Department of Publications).

We are particularly encouraged by changes to the Journal Oversight Committee (JOC). Its mandate has been expanded and its membership revised to provide an excellent framework for key decision-making affecting the future of CMAJ. The JOC now has clear responsibility for the annual performance review of the Journal and the Editor-in-Chief and for making recommendations to the CMA Board of Directors regarding employment of the Editor-in-Chief, as well as a major role in dealing with matters of contention between the Owner, the Editor-in-Chief and the Publisher. The written contract for the Editor-in-Chief, who will be appointed for a 5 -year term, will clearly specify terms and conditions, including key accountabilities and responsibilities, the parameters for the annual performance review, and procedures for renewal and termination. The CMAJ mission statement and the Journal's key goals and objectives (see online Appendix I, available at www.cmaj.ca/cgi/content/full/I75/5/453/DCI) will be the foundation for editorial decisions.

In short, the new governance structure will smooth the road ahead as CMAJ builds on its history as Canada's premier peerreviewed general medical journal and continues its prominent role in the international literature. Already, $C M A P$ s new governance structure is being recognized by other associations as a model for journal publishing, a strong signal of the importance and visionary nature of the Governance Review Panel's work. Although there may be unexpected and controversial curves in the road ahead, the new governance plan and a renewed atmosphere of trust, integrity and good faith among the parties will allow $C M A J$ to press forward at good speed. The signposts along the road are indeed positive ones. - Noni MacDonald, Acting Editor-inChief; Bruce Squires, Editor Emeritus; David Hawkins, Senior Editor; Jocelyn Downie, Advisor to the Interim Editorial Board; and the Interim Editorial Board: Arnold Aberman, Paul W. Armstrong, Frank Davidoff, Allan Detsky, Judith Hall, Brian Hennen, Jean Rouleau, Claude Roy, Jeff Scott and Donna Stewart

\section{REFERENCES}

I. CMAJ Governance Review Panel. Final report. Ottawa: The Panel; 2006 July I4. Available: www.cmaj.ca/pdfs/GovernanceReviewPanel.pdf and www.cmaj.ca/pdfs lappendices.pdf

2. Editorial independence and accountability. A submission made by the CMAJ Acting Editor-in-Chief, Editor Emeritus, and Interim Editorial Board and Advisor to the ad hoc CMAJ Governance Review Committee. Ottawa: CMAJ; 2006 May Io. Available: www.cmaj.ca/pdfs/messagefromeditor.pdf

3. CMA accepts CMAJ Governance Review Panel recommendations [press release]. Ottawa: Canadian Medical Association; 2006 July I4. Available: www.cma.ca/multimedia /CMA/Content_images/Inside_Cma/Media_Release/pdf/2006/07_I4_2.pdf 